\title{
Editorial: Why No Borders?
}

\author{
Bridget Anderson, Nandita Sharma, and Cynthia Wright
}

\begin{abstract}
This editorial article argues for No Borders as a practical political project. We first critically examine borders as ideological, generating and reinforcing inequality. We consider some responses to injustices produced by borders: the call for "human rights"; attempts to make immigration controls more "humanitarian"; and trade unions' organizing and campaigning with undocumented workers. Recognizing the important contributions of some of these responses, we argue that nevertheless they have often been limited because they do not question sovereignty, the territorializing of people's subjectivities, and nationalism. No Borders politics rejects notions of citizenship and statehood, and clarifies the centrality of borders to capitalism. We argue that No Borders is a necessary part of a global system of common rights and contemporary struggle for the commons. The article concludes by highlighting the main themes of the papers that make up the Special Issue, a number of which explore practical instances of the instantiation of No Borders politics.
\end{abstract}

\section{Résumé}

Le présent article de tête présente le mouvement No Border comme projet politique pratique. Les auteurs examinent d'abord de façon critique les frontières en tant qu'idéologie produisant et renforçant l'inégalité. Ils considèrent quelques réactions aux injustices produites par les frontières: appels aux «droits humains", tentatives de rendre les contrôles d'immigration plus "humanitaires", mouvements syndicaux d'organisation et de lutte avec les travailleurs sans-papiers. Reconnaissant l'importante contribution de certaines de ces réactions, ils soutiennent qu'elles sont néanmoins souvent limitées parce qu'elles ne mettent pas en cause la souveraineté, la territorialisation des subjectivités individuelles et le nationalisme. Le mouvement No Border rejette les notions de citoyenneté et d'État et met au grand jour le rôle central des frontières au sein du capitalisme. Les auteurs soutiennent que No Border est un élément nécessaire d'un système mondial de droits communs et de lutte contemporaine pour les communes. Ils mettent enfin en évidence les thèmes principaux des articles qui composent ce numéro spécial, dont plusieurs étudient des cas pratiques de la manifestation des politiques No Border.

$$
\begin{array}{r}
\text { Only the battles which aren't even begun are lost at the start. } \\
- \text { Madjiguène Cissé, } \\
\text { spokesperson for the Sans-Papiers in France }
\end{array}
$$

A cross the world, national states, especially in what the Economist likes to call the "rich world," are imposing ever more restrictive immigration policies. Such state efforts are being enacted at precisely the time when migration has become an increasingly important part of people's strategies for gaining access to much-needed life resources. These may be a new livelihood, closeness to significant persons in their lives, or escape from untenable, even murderous, situations, such as persecution and war, as well as the opportunity to experience new people, places, and situations. That the greater freedom of mobility granted to capital and commodities through neo-liberal reform has taken place alongside this lessening of freedom of mobility for people has been analyzed by many as constituting one of the great contradictions of the present era.

In contrast, in this Special Issue on the emergence of a No Borders politics, we show that the simultaneous process of granting more freedom to capital and less to migrants is far from a contradiction and is in fact a crucial underpinning of global capitalism and the equally global system of national states. The growing restriction on the freedom of people to move has not led to fewer people crossing nationalized borders. Exactly the opposite: today more people are doing exactly this than ever before. The United Nations Population Division currently estimates that there are now about 200 million international migrants each year. This 
represents a doubling of the numbers of people engaged in cross-border migration in $1980 .^{1}$

Though their main accomplishment is not the restraint of people's movements, restrictive immigration policies do have an effect. Increasingly militarized border controls, for instance, have increased the costs paid for migration, be it the monetary cost of securing passage, the extraction of labour, or the cost of one's own life. Not only are there a growing number of nominally temporary camps (refugee camps, detention camps, transit camps, and so on), but more and more dead bodies are being found washed up on the shore, in scorched desert valleys, on frozen mountain passes, or in any number of other dangerous crossing points through which migrants have been funnelled. ${ }^{2}$ This has allowed national states to cynically claim that the greatest threat to migrants are those who assist them in their movement, thereby deflecting blame from their own border control practices and setting the stage for further criminalizing "traffickers" and "smugglers."

The greater though less studied effect of restrictive immigration policies has been to restrict the rights and entitlements that migrants can claim once they are within national states. In practice, rather than simply restricting movement, restrictive immigration policies have enabled states to shift the status they accord migrating people. Fewer people are now given a status that comes with rights (e.g., "permanent resident" or "refugee") and more and more are legally subordinated (e.g., through the status of "illegal") or are forced to work in unfree employment relations (including through the status of "temporary foreign worker"). ${ }^{3}$ Since 2005 in the US more migrants are given the status of illegal than all of the various legal statuses combined. ${ }^{4}$ In Canada, more people enter as temporary foreign workers than as permanent residents. ${ }^{5}$ Such a situation calls into question the oft-stated purposes served by the entire array of contemporary migration controls-the totality of which has made many migrants more vulnerable and their lives and livelihoods more precarious.

One important and underexamined response to this historical conjuncture is the emergence of calls for No Borders. These are made on the basis of interrelated ethical, political, social, and economic grounds. Their challenging of nationstates' sovereign right to control people's mobility signals a new sort of liberatory project, one with new ideas of "society" and one aimed at creating new social actors not identified with nationalist projects (projects that are deeply racialized, gendered, sexualized, and productive of class relations). As a practical, political project develops against borders, its relevance to other political projects grows, often challenging them in profound ways. There is a mounting need, therefore, to open an intellectual and political environment in which arguments for No Borders are further debated. It is with this goal in mind that we have put together this Special Issue on No Borders.

In this introduction we first consider what borders are and how they are constructed and examine some of the critical responses to borders, their possibilities and limitations. We identify some of the key problems with these approaches, in particular the assumption that migration is a problem and that the nation-state framework persists unchallenged. We then describe some of the elements of a No Borders approach and refute the claim that it is utopian. We examine the centrality of migrants to the more general liberatory project that is No Borders and go on to indicate some of the contributions made by the papers in this Special Issue.

\section{Rethinking Borders}

What is a border? Any study of national borders needs to start with the recognition that they are thoroughly ideological. While they are presented as filters, sorting people into desirable and non-desirable, skilled and unskilled, genuine and bogus, worker, wife, refugee, etc., national borders are better analyzed as moulds, as attempts to create certain types of subjects and subjectivities. Thus borders are productive and generative. They place people in new types of power relations with others and they impart particular kinds of subjectivities. Borders, then, are the mark of a particular kind of relationship, one based on deep divisions and inequalities between people who are given varying national statuses. It is important to recognize that this has far-reaching implications and is not simply restricted to the event of crossing a territorial border.

If not only territorial, where is a border? Borders are not fixed, even though their work is all about fixing, categorizing, and setting people in new relations of power. As Mae Ngai carefully details, borders are not only territorially drawn: they inevitably are inscribed "inside" as well as "outside" of any given national state. ${ }^{6}$ Indeed, Étienne Balibar contends that borders exist not only "at the edge of the territory, marking the point where it ends" but "have been transported into the middle of political space." 7 Borders follow people and surround them as they try to access paid labour, welfare benefits, health, labour protections, education, civil associations, and justice. Those who are given a subordinated status by the state, such as "temporary foreign worker," typically do not have the right to change employer or type of employment, a right that "citizens" of liberal democracies now take for granted. Those who are deemed "illegal" are vulnerable to being reported by employers, landlords, police, the concerned public, and even "friends." Breaking the regulations and laws governing entry, residence, and access 
to work and services can result in detention and deportation. Michael Walzer's fear of "a thousand petty fortresses" that he predicted would attend a borderless world is already being realized, though the barriers pass largely unnoticed by citizens, who take access across them for granted. ${ }^{8}$

Nevertheless, despite their assumption of free passage, citizens are not exempt from the power of borders, and their impact is both direct and indirect. ${ }^{9}$ In the UK fear of "foreign national terrorists" has resulted in the development of Control Orders. These originally provided the state with the legal authority to indefinitely detain non-citizens without trial if a trial put secret intelligence at risk. When this was found to be discriminatory, instead of ending the practice, the state's powers were simply extended to citizens. The loss of civil liberties for citizens thus is often foretold by the treatment of non-citizens. More indirectly, there continue to be claims by employers that "local workers" (of whatever nationality) are "lazy" and that migrants have a "good work ethic." However, it is immigration controls that give employers greater power over migrants, particularly new arrivals or those who are dependent on them for their visa status, a power they do not always have over citizens. ${ }^{10}$ While these divisions are often naturalized and expressed in terms of culture and national stereotypes, they are directly produced, and have the additional merit of serving a disciplinary function over citizen-workers, fostering resentment and competition rather than solidarity.

It is not only "hard workers" who are produced at the border. "Good wives" who do not challenge patriarchal families, "straight guys and gals" who adhere to correct sexual scripts, "good parents" whose parenting accords with the requirements to produce "good children" are policed through immigration requirements. ${ }^{11}$ Such requirements rest on ideological, even fantastical, re-presentations of the "nation" that states nominally "represent." This is reflected in a new Citizenship Guide released by the Canadian state in 2009. Meant as a study tool for new applicants for citizenship, it not only defines Canadian-ness in starkly neo-liberal terms-one must be the citizen-worker who is part of a selfreliant family-it also reproduces old racist, colonial scripts. Along with "[g]etting a job, taking care of one's family, and working hard in keeping with one's abilities," the guide tells immigrants that Canada is a place where "... men and women are equal under the law" and warns them that "Canada's openness and generosity do not extend to barbaric cultural practices that tolerate spousal abuse, 'honour killings,' female genital mutilation, or other gender-based violence." 12 While male violence against women, significant pay differentials between men and women, sexual abuse of children, and other heinous activities are not uncommon features of life in Canada, "immigrants" are ideologically set apart from "Canadians" so as to imply the latter's superiority.

Questions of citizenship point to the temporal aspects of borders. This leads us to ask: when is the border? Temporal aspects of migration and their consequences can pass unnoticed by scholars, but they structure people's experiences of borders and, increasingly, state responses to migration. Being able to imagine a future with oneself in it (even if, at the time of imagining, a person is content with living in the moment), feeling that one can anticipate and take risks, and have a sense of possibility, these are important aspects of human experience and subjectivity. Immigration controls and the relationships that they generate undermine these and can force people to live in an eternal present. Studies of those working without state endorsement, for example, find that the extreme insecurity of their situation results in the intensification of their working time and effort-with increased profitability for their employer.

The temporality of borders mean that migrants on renewable working permits, spousal visa holders, children, and students live in a state of dependency on others for their continued legally recognized residence in a state. Those who are on temporary visas, like those who are going through the years of legal wrangling of immigration and asylum challenges, find themselves suspended in time with devastating consequences. Time, however, does not stop: relatives may die without being visited, children become too old to be granted the right to be with parents and carers, opportunities are missed. Such consequences have intensified as states have fortified their territorial borders and curtailed the ability of people to move out of national states in which they live their lives as "illegals." There has been an important and largely unrecognized shift by states to exert greater control over these temporal aspects of mobililty, in particular through the encouragement of temporary worker programs and the ever increasing obstacles to citizenship.

\section{Rethinking Protest}

The contradictions and injustices of borders have not passed unnoticed, and in recent years there has been considerable debate about the intrinsic tension within the liberal project between imagined national belonging on the one hand and universal human rights on the other. Anti-racist and transnational feminist accounts ${ }^{13}$ - themselves informed by migration histories and by activist confrontations with "the citizenship machinery"14-have begun an inquiry into the production of non-citizen Others. As we will argue below, this theoretical legacy, along with labour internationalism, can be renewed-and greatly extended-through an engagement with an anti-capitalist No Borders politics. There has also been a myriad of attempts to make ideas of citizenship 
compatible with human rights, both theoretically and in practice. ${ }^{15}$ The practices of states in terms of both entry and deportation are constantly being challenged legally and politically with reference to human rights claims even as it becomes obvious that human rights frameworks themselves assume citizenship, rely on the compliance of national states for enforcement, and are (therefore) especially unhelpful when it comes to the claims of the illegalized. ${ }^{16}$

The position of migrants demonstrates the limitations of theoretical scholarship and practical-political projects that assume, explicitly or implicitly, national citizenship as the ground on which political mobilizations, claims, and rights ought to be organized. ${ }^{17}$ The fact is that citizenshiprights-based NGO approaches, whether at the national or transnational level, are very limited in practice. ${ }^{18}$ For a start, none of the current citizenship-rights-based frameworks are ultimately prepared to challenge frontally the right of states to control their borders and territories, or the rights of states to exclude and deport. Additionally, citizenshiprights-based approaches often reinforce a rather passive politics in which, as has been argued, claims are made through judicial processes and NGO approaches that can take organizing and political contestation-politics, in short-out of the hands of people. ${ }^{19}$

Alongside arguments for the extension of citizenship rights to those currently excluded, there are a number of attempts (at various scales of space and politics, and from diverse standpoints) to make immigration controls "humanitarian." Among the most globally influential-and deeply problematic-is purported attempts (whether by states and policing bodies, NGOs, or religious or women's groups) to end "human trafficking." Indeed, it is the Victim of Trafficking-often figured as a woman in the sex industry-who has now become the symbol of concern for noncitizens (until the last decade it was the "refugee"). ${ }^{20}$ Under the discursive practice of "anti-trafficking," immigration controls and enforcement are argued as needed for the protection of migrants themselves, particularly since those who are illegal can be "vulnerable and often desperate people." 21 The language of harm prevention and protection that has slipped into immigration enforcement at a now global scale is extremely powerful. While the scope of positive duties may be controversial, the prohibition of harm is something that people with very different political opinions find relatively easy to agree upon. This has meant that borders are increasingly presented as points of humanitarian intervention where states can protect the local labour force and businesses from unfair competition, and protect migrants from abuse and exploitation.

However, the problem with the language of protection and harm is that it inscribes the state as an appropriate protector for vulnerable migrants. This is deeply problematic. Firstly, migrants are not naturally vulnerable; rather the state is deeply implicated in constructing vulnerability through immigration controls and practices. As has been argued above, immigration controls are not neutral but productive: they produce and reinforce relations of dependency and power. Concern with trafficking focuses on borders and immigration controls while missing the crucial point that immigration controls create the relations of domination and subordination that they are then said to relieve. This, handily, leaves the work that national states do to produce illegality and (im)migrants' vulnerabilities completely out of the picture. Secondly, and relatedly, it leaves no room for migrants' subjectivities, engagements, and actions. They are constructed as objects of control, rescue, and redemption rather than as full human beings. This is especially the case for anti-trafficking discourses directed at sex work, since they allow "women's sexual purity to be rescued in the national imagination." 22 As Brace has written in her exploration of the politics of abolitionism:

Once you value powerlessness, then you are buying into a politics that cannot be transformative because it cannot explore capacities, contingency and multiplicity, or engage in the affairs of the world. Part of the problem of focusing on the victimhood of slaves, is that their labour disappears, making it harder to see how they are engaged with the world and part of our own moral economies and global markets. ${ }^{23}$

An engagement with the practices of workers' rights, including migrant sex workers, goes some way to countering these challenges. Rather than construct an abstract rights-bearing human through human rights discourses, it makes more sense to start from a theoretical standpoint that rethinks - and fundamentally relinks-labour and spatial practices. ${ }^{24}$ The struggle and power relations that can be obfuscated by the language of human rights are more visible in the language of workers' rights, which also signify a call to collective action and organizing. Many in the mainstream of US labour unions, to take one nationalized context, have since the mid-1970s begun to realize the importance of showing solidarity with (im)migrant workers, including, at times, the illegalized and those on temporary labour contracts. Undocumented workers wield strategic power in a number of sectors of the US economy in key cities such as Los Angeles, as a substantial labour scholarship and impressive organizing history has made clear. Indeed the solidarity of some trade unions is often as a result of migrants having taken a leading role in important trade union organizing. ${ }^{25}$ This marks a real step forward in practical politics. 
However, in expanding their organizing efforts to include the paperless, most US unions (and many unions globally, especially in the "rich world") have not given up on their nation-state-centrism and their advocacy of restrictive border controls. They have not challenged borders and the institution of national citizenship itself. Their focus, at best, continues to be on achieving better immigration laws even while arguing for the further securing of the border and even, at times, for the placement of migrants into subordinated categories of "guest workers." Thus, while organizing those (im)migrants currently within the national state, unions continue to demand that future migrants be shut out. $^{26}$ In this sense, the borders surrounding labour solidarity are both spatial and temporal: current (im)migrants are included within the expanded line drawn by contemporary unions and are seen as fit for union membership but future migrants continue to be seen as a threat to labour solidarity. ${ }^{27}$

The limitations of many contemporary mainstream trade union approaches is not accidental, but written deeply into the history of nationalized labour movements. Many of these approaches arose precisely to restrict or exclude particular forms of subordinated labour including migrant labour and the labour of women. This was typically constructed as "unfree" and consequently racialized, above all if workers came from currently or formerly colonized places. As historian Donna Gabaccia argues, "Indeed, it sometimes seems that nineteenth-century observers had to label migrants as unfree in order to exclude them as racially undesirable." ${ }^{28}$ In the process, vast differences in labour practices and levels of coercion were collapsed. Of course, there was also an alternative internationalism to be found in this period in such radical proletarian formations as the International Workers of the World, and the global syndicalist tradition-a tradition that largely went down to defeat. As Gabaccia concludes, "To defend free labor, labor activists had curtailed free migration. Immigration restrictions in turn helped to replicate under capitalism some of the inequalities of colonialism." 29

It is to address these inequalities (and their accompanying forms of racism and xenophobia) that diverse immigrant rights projects have therefore addressed themselves-sometimes in conjunction with organized labour or para-labour formations, and sometimes not. Many have focused on "fixing" the immigration system, on seeking legal and legislative reforms, on making it more "fair and just." Still other projects have focused primarily on the many problems with the post-World War II international refugee regime, while also often reinforcing unsustainable divisions among various categories of migrants ("refugees," "illegals," "economic migrants," and so on). In the US and Canadian cases, demands for legalization (or regularization) of undocumented and precarious-status workers (including failed refugee claimants) have featured prominently even as the possibilities for such a policy option have receded rapidly, thereby opening up the ground (as we shall explore in more detail below) for more radical alternatives. ${ }^{30}$ State-led regularization programs, often centred on recognizing a person's contributions to a workplace, have typically been tied to further tightening of the borders (and therefore have served to further reproduce states of illegality).

Importantly, not everyone counts as a worker, and, not everyone wants to count as a worker. The gendered history of the institution of wage labour means that the regularization demand cannot adequately encompass, for example, gendered unpaid reproductive and domestic labour, not to speak of paid sexual labour. ${ }^{31}$ Thus, at the same time as acknowledging the importance of labour organizing within a migrant justice context, we must not forget the production of gender, sexualities, families, and households, as well as the production of labour relations, that is a function and consequence of borders. Moreover, we must keep in mind another border, that between the "public" and the "private," a central divide within the institution of citizenship. ${ }^{32}$ That divide simultaneously devalues and genders labour, and means that only certain types of work are regarded as work, as much rich feminist scholarship on social reproduction, the welfare state, the institution of wage labour, and citizenship and immigration has elucidated. ${ }^{33}$

\section{Rethinking Migration as a Human Activity}

A general problem with the above approaches is their shared assumption concerning the human practice of migration. For them, migration is always-already a problem: an aberrant form of behaviour in need of fixing. Consequently, people's mobility is seen as only ever caused by crisis and as crisis producing. ${ }^{34}$ Their ideal view of the world is one in which people seldom, if ever, move and societies remain more or less "closed." Such a view belies the history of humanity. Historians, archaeologists, biologists, and the tales that people tell all point to the fact that around the world human beings have always moved and that they have done so for reasons not dissimilar to the reasons people move today. Yet, in most nationalist narratives, "the people" are seen as attached to particular lands in ways that are either primordial (they themselves are portrayed as "rooted" to the land) or providential (they were "destined" to be on certain lands). ${ }^{35}$ The invention of human sedentarism or doctrines of Manifest Destiny rests on problematic assumptions about what migration actually is and who engages in it. ${ }^{36}$ 
It is crucial to note that while millions of people move about, only certain people are classed as "migrants." This is not simply to do with length of stay: a tourist may only be resident for a short period, but then, so is a temporary worker; neither is it to do with employment-how many of us attending international academic conferences write down that we are present "for the purposes of employment" even though we are scarcely going for a holiday? Who counts as a migrant depends on who is doing the counting, and on the purpose of the counting. It is shifting and contradictory. There are multiple ways and scales by which the figure of "the migrant" is imagined, defined, and represented (both in the abstract and in the particular). The figure is generally negatively gendered, racialized, and classed: US financiers, Australian backpackers, and British "expats" are not, generally, constructed as migrants. It is not just the state, but a wide range of other actors, including local government, academia, the media, NGOs, trade unions, and the daily practices of individuals (both citizens and non-citizens) that work with and against each other to construct and identify who counts as a migrant. However, one thing that all these constructions have in common is that the constitution of "the migrant" is nation-state-centric. One might move thousands of miles or only a few feet but whether one is seen to be migrating or not ultimately rests on whether one has crossed a nationalized boundary. Hence, working with the often racialized and gendered understanding of who constitutes a national subject, the legal meaning of migrant rests on the idea of the "foreigner." 37

The "foreigner" is a very special figure in the global systems of capitalism and national states. Today, the foreigner is someone who can be legally (and often socially) denied most, if not all, of the rights associated with membership in a national state (and the associated ideological understanding of membership in a nation). Mobility controls are largely directed at "managing" the movement of foreigners. However, it is important to recognize that in the initial period when regulations on people's mobilities were put into place in the emergent global system, it was people's movement out of the realms of rulers that was the main concern. Yet, like today, early controls on mobility were very much related to the creation and maintenance of a proletariat, that is, a commodified workforce for (at the time, nascent) capitalists.

For example, the original Poor Laws in England were designed both to control the mobility of peasants fleeing their now-privatized commons and to coerce those classified as "vagabonds" into working. ${ }^{38}$ As states developed, controls of the movement of the ruled were pushed to nationalized borders. ${ }^{39}$ Historically (and currently) coerced immobility acted to discipline the unruliness of the expropriated in order to make them productive workers whose labour power could be exploited. Indeed, capturing and containing a potential workforce by compelling them into not moving was a key element in making nascent capitalist ventures possible. It is in part for this reason that early passports were designed to control people's exits from, not their arrivals into, the territories controlled by various ruling groups. ${ }^{40}$ Mobility out of a particular space was defined as a major problem by and for those who needed a sedentary workforce. Thus, as Papadopoulos, Stephenson, and Tsianos note, "It is no coincidence that the word mobility refers not only to movement but also to the common people, the working classes, the mob." It was this mob and their attempts to flee expropriation and exploitation that posed one of the greatest threats to the success of capitalism. ${ }^{41}$ And, it was, in part, their sedentarization that helped to ensure its success. The word "state" derives from "stasis" or immobility.

Relatedly, criminalizing people's mobility and denying access to resources, services, and rights to those deemed to be illegally migrating and residing in a place was an important part of how the modern proletariat was formed. As today, it also served as a method for the creation of "cheap labour." "Above all," as Sucheta Mazumdar notes, "new states and institutions marking borders and passports developed only after the slave trade ended" and in a context in which migrants and migrations continued to be shaped by the continuing legacy of slavery, apartheid, and diverse forms of unfree labour. ${ }^{42}$ In the context of the formerly colonized world, immigration controls, and the expelling of "nonindigenous" workers, as well as other forms of state-sponsored xenophobia, was a feature of many newly independent states. ${ }^{43}$ That people continued to move, despite strictures against their mobility, demonstrates both the historical futility of border controls but it also demonstrates that, like today, an illegalized workforce was a boon to employers. Another similarity to today's world: those who moved without the state's permission were represented as dangerous for the emerging world system, even though this same system was built on the making of distinctions between legal and illegal persons.

Together, restrictions on mobility and the subordination of those who moved without permission worked to territorialize people's relationship to space, to their labour, and to their ability to maintain themselves. One's wage rates, access to employment, to rights, to welfare benefits, to land, etc. were all bound to one's recognized legal residence in particular spaces. Thus, through attempts at rendering people immobile, "[b]odies become territorialized; people become subjects of a specific territory, of a sovereign power." 44 As rights and livelihoods were territorialized, so were people's subjectivities. The result? We've got a world 
where nationalism is, as Benedict Anderson notes, “... the most universally legitimate value in the political life of our time."45

\section{Elements of a No Borders Approach}

Since the creation of the very first illegalized person, whenever and wherever controls have been placed on people's movements, they have been rejected. As William Walters comments, "In certain respects the power of autonomous movement has been the hidden secret of the history of class struggle." ${ }^{6}$ Some have offered a philosophical rejection of the limits to the human activity of migration. Others have rejected the territorialization of their subjectivity and their relationships. Still others have rejected attempts to make them live a life that has become untenable due to acts of expropriation, terror, and/or impoverishment. No set of border controls has ever worked to fully contain people's desire and need to move. In this sense, it can be argued that an everyday practice of refusing the border has existed as long as borders have.

A contemporary politics for No Borders can, nonetheless, be said to have emerged in the mid-1990s. It is marked by the repoliticization of the very legitimacy of (im)migration restrictions and the distinctions made between "national" or even "regional" or "continental" (e.g., "European") subjects and their foreigners. What distinguishes a No Borders politics from other immigrant-rights approaches is their refusal to settle for "fairer" immigration laws (higher numbers, legal statuses, and so on). Within a No Borders politics, it is understood that the border-control practices of national states not only reflect people's unequal rights (e.g., whose movements are deemed to be legitimate and whose are not) but also produce this inequality. Thus, their signal demand is for every person to have the freedom to move and, in this era of massive dispossession and displacement, the concomitant freedom to not be moved (i.e., to stay).

In this, a No Borders politics, far from reaffirming the significance of citizenship, even if it is understood "... not an institution or a statute but a collective practice," as Étienne Balibar contends, calls into question the legitimacy of the global system of national states itself and the related global system of capitalism. ${ }^{47}$ In making these demands, a No Borders politics clarifies the centrality of border controls to capitalist social relations, relationships borne of-and still dependent on-practices of expropriation and exploitation. They show that social justice movements must not only "confront" the question of the border, they must reject borders that work to multiply both control devices and differentiated labour regimes. ${ }^{48}$ In so doing, they distinguish themselves from calls for open borders made by the Right, calls that centre on the availability of persons made mobile largely because of prior instances of dispossession and displacement. ${ }^{49}$ The Right's call for open borders, thus, can be seen as a continuation, in new form, of the strategy of "accumulation by dispossession." 50

While most associated with events in Western Europe, a current No Borders politics also has its immediate predecessors in North America and is linked to prior movements for free mobility there. For instance, the popular No Borders cry that "No One Is Illegal" first arose against Operation Wetback, a 1954 US government program which resulted in over one million people being forced to leave the US for Mexico. The Sans Papiers in France, widely credited with first articulating a contemporary No Borders politics, gave new life to this slogan. Largely made up of migrants from Africa who found themselves categorized as "illegals," the Sans Papiers began in 1996 by refusing to accept the right of the French state to control their lives through rendering them "paperless." Their radical stance, and the outpouring of solidarity for them from people across the spectrum of state statuses, stood in marked contrast to the wide legitimacy given to Operation Wetback in the US and can be seen as part of the legacy of the Paris Uprising of $1968 .{ }^{51}$ Part of the French state's efforts to lessen the impact of this uprising was to begin deporting activists categorized as (im)migrants. An important response to these deportations was captured in the slogan, "We are all foreigners." That the slogan was not "We are all French" is significant and signals a kind of nascent No Borders rejection of having one's subjectivity aligned with the national state by which one is governed.

The rejection of borders and the differences they make among people (as labourers and lovers, as comrades and classmates, etc.) comes from a shift in standpoint from one centred on citizens and "their" organizations or "their" state to one that begins from the standpoint of migrants themselves. The initial organizations of a movement for No Borders were led by migrants who insisted that migrants were legitimate political actors within national polities and did not want or need citizens' groups to act as a cover for their activities. Such acts of autonomy brought back to people's attention that, in the struggle for liberty, freedom, democracy, livelihoods, and more, one needed to act with, and not against, those defined as (im)migrants and foreigners. That is, that interests between people in these two categorical groups were shared rather than conflicting.

The recognition and naming of people's refusals to accept borders is of crucial importance in the light of the typical response to calls for No Borders: that it is utopian and impractical. This is often accompanied by what Phillip Cole calls the "catastrophe prediction." 52 This argues that No Borders would undermine equality and welfare protections 
within liberal democratic states and this would have an impact on the most marginalized and disadvantaged. It is also said that a lack of borders would also erode national identities and commitments to liberal democratic values. It is this dystopic vision that allows for either the consequent Hobbesian response (that states must be given sovereignty and the power to enforce compliance in the interests of citizens) ${ }^{53}$ or the related communitarian response (in which national state formations are defended on the grounds that democracy itself can flourish only if bounded with strong insides and outsides). ${ }^{54}$ In both scenarios, national sovereignty, although potentially unjust, is cast as a necessary evil.

This vision must be challenged. It has been countered by some through claims that a world without borders would not be altogether that different: not many people would move, migration has a very limited impact on labour markets, and non-migrants as well as citizens would continue to be able to enjoy the privileges of citizenship, even if they are somewhat diminished. ${ }^{55}$ We reject the politics of these sorts of arguments. A radical No Borders politics acknowledges that it is part of revolutionary change. If successful, it will have a very profound effect on all of our lives for it is part of a global reshaping of economies and societies in a way that is not compatible with capitalism, nationalism, or the mode of state-controlled belonging that is citizenship. It is ambitious and requires exciting and imaginative explorations, but it is not utopian. It is in fact eminently practical and is being carried out daily.

This raises the question of what sorts of political communities are desirable, and we would suggest that one way of framing our responses to this could be by considering the struggle for the commons. The No Borders demand for the right to move/stay is not framed within a liberal (capitalist) praxis as are the rights of states, citizens, private property owners, or even the ambiguous and largely symbolic arena of human rights. Instead, the rights to move and to stay are understood as a necessary part of a contemporary system of common rights. Thus, while focused on realizing their demand for freedom of movement (which includes the freedom to not be moved), a No Borders politics can be seen as part of a broader, reinvigorated struggle for the commons.

Peter Linebaugh, in his Magna Carta Manifesto, has identified four key principles historically evident in the practice of commoning and in the rights held by commoners, rights that differ substantially from the modern regime of citizens or human rights. ${ }^{56}$ First, common rights are "embedded in a particular ecology," one that is reliant on local knowledge of sustainable practices. ${ }^{57}$ In this sense common rights are neither abstract nor essentialist but are based on one's actions. Secondly, "commoning is embedded in a labor process" and is "entered into by labor." 58 Hence, commoning, by definition, rejects parasitic class relationships centred on the dialectic of exploiters and producers. Third, "commoning is collective." 59 That is, it is a social practice. Fourth, commoning is "independent of the state" and the law. ${ }^{60}$ There are no sovereigns in the commons. In sum, commoning is the realization of not only political rights but also social and economic rights of the commoners. Commoning, as a practice, then, resolves the capitalist separation of falsely divided spheres. Common rights have historically included the principles of: neighbourhood; subsistence; travel; antienclosure; and reparations. ${ }^{61}$

Key to the realization of a commons is the nurturing of relationships of mutuality with fellow commoners. The rights held by commoners are the rights of persons. In contrast to the rights of property, consisting of the right to exclude others from enjoying that which has been privatized, the right of persons consists of the right to not be excluded. ${ }^{62}$ Thus, the right of persons is not something that is granted. Instead, it is an entitlement that each person carries in her/himself. Dependent upon adherence to the above key principles of commoning, to have the right of persons entitles one to the resources of society. It includes the right to not be distinguished from others who also carry the right of persons. We contend that it is this right of persons in the commons that alone can build the foundation by which to construct a society of equals. Indeed, we argue that the political, No Borders demand for the right to move and to stay ought to be seen as a necessary part of a contemporary common right of persons.

Today's commons is seen as being operational only at a global scale and, therefore, against the nation (e.g., citizenship) or even the region or the continent (e.g., the European Union). From an ecological perspective, we have long known that destructive (or helpful) practices in one part of the globe have effects, sometimes immediate, on all others. From a social perspective, creating restrictions on the movement of people, plants, animals, food, fuel, medicines, ideas, and more in a world that has long come to be shaped by such movements is tantamount to accepting the imposition of inequalities of one sort or another. Thus, the commons for which a No Borders politics struggles is a global one. Many taking a No Borders political position, therefore, move from challenging national forms of belonging to trying to activate new subjectivities, ones that correspond with the global level at which human society is actually organized, in order to affirm a conception of freedom based on the collective political action of equals. A No Borders politics, thus, redefines equality by positing it as a relationship among co-members of a global society and not one among national citizens. 
What a No Borders politics demonstrates is that despite the proliferation of what Walter Mignolo has called "border thinking," borders and their institutional relation, citizenship, like states and nations, are highly volatile and unstable. ${ }^{63}$ While this means that borders are adaptable it also means that their authority can be challenged, indeed it is challenged on a daily basis. Awakening ourselves to the political potential of these challenges is an important aspect of No Borders struggles.

Under a general rubric of No Borders (if not always explicitly) are a wide variety of individuals and groups. They include groups of self-conscious activists directly confronting the state's imposition of barriers to people's mobilities (be they migrant detention camps, deportation schemes, harassment by various arms of state, and ejection by landlords). Examples of such groups are the Sans Papiers in France mentioned above and groups inspired by their actions, such as the Sin Papeles in Spain. In Europe, there is also the broader No Border network, a loose affiliation of individuals, sometimes in organizations, who unambiguously reject any controls on people's migration and stage demonstrations and solidarity events with detained migrants. In South Africa, the recent wave of terrible attacks on migrants, resulting in dozens of murders, led to important organizing among shack-dwellers who issued a powerful manifesto against such killings, against xenophobia and for common rights for all. 64

Informed by a No Borders politics there also exist campaigns that attempt to eliminate the use of (im)migration status as a tool of control of migrants. These include "Don't Ask; Don't Tell" campaigners in the US and in Canada calling for an end to citizenship and immigration status distinctions among people in the provision of social services and in the receipt of protection (against patriarchal violence, substandard employment conditions, etc.). Elsewhere, there exist groups such as Doctors of the World who provide needed medical assistance without applying status or residence restrictions on the receipt of aid. Such groups often call for legalization (or regularization) of illegalized migrants as a means by which to gain rights and entitlements currently restricted to citizens and some permanent residents.

Under the rubric of No Borders there are also groups who may not be entirely committed to the abolition of borders, nation-states, and capitalism but who, in their everyday activities, provide much-needed support, be it in the form of information, shelter, water, and food to travelling migrants, or when trade unions purposefully ignore a person's (im)migration status in their organizing drives or even specifically address the vulnerabilities faced by persons because of their lllegal or temporary status. Also active are other individuals and groups who argue for the abolition of the multiple borders that national states impose, such as borders created by laws regarding "official languages" and other, "banal nationalisms." 65 These include groups such as "No More Deaths" which works at the US/Mexico border and labour unions such as Justice for Janitors in the US and Canada and the United Food and Commercial Workers Union in Canada. These unions have crossed the ideological divide created by the state between nationals and foreigners in order to secure higher wages, better working conditions, and health care for any worker in the occupational sectors they organize. Indeed such a rejection is what, in part, links disparate campaigns, groups, and individuals together within a broader No Borders politics.

\section{The Challenge of No Borders}

This issue considers practical No Borders politics across a range of sites engaged with a wide range of political projects. What they have in common is their de-naturalization of the figure of the migrant or the refugee, and a refusal to accept dehumanizing bordering practices. This necessitates going beyond state-imposed categories and, as Shourideh Molavi and other contributors argue, that we also move beyond the rehearsing of the arguments about de facto and de jure citizenship to think about new forms of relating each to one another other than the model of citizenship and subjecthood. One of the most obvious consequences of these, as we have discussed above, is the promotion of competition among workers: immigration controls promise to protect a nationalized labour force from competition by foreigners said to threaten to undermine terms and conditions. However, rather than keeping non-citizen workers out, in practice they help create a group of workers that can be more preferable to employers because they have additional mechanisms of control over them, including the threat of deportation. This may be through illegalizing their labour, or it may be by tying them to particular employers. As Luke Stobart argues in his essay, organizing migrant workers, whatever their legal status, needs to be centralized rather than an "optional extra."

The call for No Borders requires us to rethink our responses to what Michael Billig called "banal nationalism." "66 This theme is taken up by Carolina Moulin who describes how cities can be the site of new forms of politics and struggle-as well, of course, as administrative units that are used by the state in its creation and enforcement of borders. No Borders politics demands a response and engagement from all of us, not only migrants, trade union activists, and those who are engaged with migrants' struggles. For we are all implicated in the endless drawing and contesting of borders. Clemence Due and Damien 
Riggs explore empirically how borders are created on the playground through the practices of teachers and children. The paper presents the difficulties of "integration" as not being about a deficit in individual migrant children but about their differential categorization and the steadfast refusal to see their relations, contributions, and needs. This is a refusal, in fact, to see the border as created and enacted in the playground, partly because of the naturalization of categories of migrant and refugee and can be seen as acts of banal anti-nationalism.

Jean $\mathrm{McD}$ Donald critiques regularization programs at the same time as acknowledging that they do bring practical improvements to the lives of some individuals. She discusses how criteria for regularization produce subjects and reproduce ideas of the nation. Migrants must prove themselves "deserving" of regularization. There is an explicit discussion of criminal inadmissibility for regularization programs. This is the case not just in Canada but in many states, including the US and the UK. The "Foreign National Prisoner" is an important (spectacular) figure in the justification of enforcement policy and practice, a rallying point whose deportation can be universally agreed on. While there may be protest at the deportation of "hard workers," "good neighbours," and "lovely parents," this can rest on communitarian ideals of belonging. There are few antideportation campaigns fought in solidarity with foreign national prisoners, and this group has become an important figure in liberal democracies' enforcement as the acceptable face of deportation. 67

There is a spectacular nature to border control, manifest in the deportation of foreign national prisoners: for instance, high profile raids, and the panoply of walls, technologies, and uniforms that mark them out. But at the same time borders are normalized and mundane. Andrew Burridge reveals the brutal mundanity of borders. The spectacular, with its tales of victims and villains, can divert attention from the structural underpinnings of the life stories that are held up to view. As the paper points out, dramatic rescue narratives avoid the question of who and why people need to be "saved" in the first place. Witnessing and rejecting the mundane is clearly an important aspect of the work of border activists.

No Border politics can also be an everyday practice, as the paper by Tara Polzer makes clear. People endlessly learn from, relate, and adapt to each other, and these relations, processes, and practices are often distorted, rather than facilitated, by "integration policies" that are imposed from above. The social practices of bordering which are crucial to rendering it so mundane are also emphasised by Nick Gill. His discussion is useful because it discusses the different politics of No Borders and shows that the call for No Borders can mask very different attitudes to capitalism as well as to nation-states. In this respect, the importance of the challenge to work-centred instrumentalism as described by Amarela Varela becomes particularly clear. Borders and nationalized identities are a key strategy in dividing and subordinating labour and this insight is important to an anti-capitalist No Borders politics, but it is important too to recognize that not everybody imagines themselves as a "worker," and there are more ways of engaging with the materiality of the world and with each other than is captured by the term "work." Thus Amarela Varela describes the possibility of moving away from "workcentred instrumentalism." In a very direct way she demonstrates how the granting of the call for the right to reside "stabilized" people and brought them under state authority. The documents were granted only contingently and in such a way that they required migrants to work and pay taxes in order to maintain their status. She argues that it is not "regularization" that is required and, instead, calls for "a different politics" that entails equality and respect for all.

It is clear that there is a great deal of discussion and debate within the emergent politics of No Borders, a discussion we hope to contribute to with this Special Issue. The papers gathered here acknowledge the many new opportunities for praxis which require listening to the theorizing of those who reject borders and the entire apparatus of nation-states, global capitalism, and bounded imaginations which give them support. These papers further demonstrate the enormous and always hierarchical differences organized through the institutions and relationships made by borders, nation-states, and capital, differences often further ensconced by current social movements which advance the rights of only one or another particular state category of persons, be they "citizens," "immigrants," "refugees," or others. Taken in their entirety, these papers offer us a "line of flight" away from the struggle of differentiated rights and towards the recognition of a common right of movement, livelihood, and full and equal societal membership for all.

\section{Notes}

1. From 1980 to now, there has also been an increase in the overall global population of humans. Taking this into account allows us to understand that international migration has remained more stable than the sheer numbers would indicate. Nonetheless, it is important to note that a large proportion of the world's people continue to see migration as an important part of their life strategies. Unlike in 1980, however, their ability to secure rights following migration has become severely restricted. See the Global Commission on International Migration (GCIM), "Migration in an Interconnected World: New Directions for Action," Report (2005):1; 5-6. GCIM; online: http://www. 
unhcr.org/refworld/docid/435f81814.html (accessed July 20, 2010).

2. Joseph Nevins, Operation Gatekeeper: The Rise of the "Illegal Alien" and the Making of the U.S.-Mexico Boundary (New York and London: Routledge, 2002); Liz Fekete, "Death at the Border-Who Is to Blame?" European Race Bulletin no. 44 (2003): 2-3.

3. We initially place state categories of citizenship and immigration within quotation marks to problematize them and highlight their socially constructed character. We don't continue with this practice for the sake of easier reading.

4. Jeffrey S. Passel and Roberto Suro, "Rise, Peak, and Decline: Trends in U.S. Immigration 1992-2004" (Washington, DC: Pew Hispanic Center, 2005), online: http://pewhispanic. org/reports/report.php?ReportID=53 (accessed July 12, 2010).

5. Nandita Sharma, “'Race, Class and Gender and the Making of 'Difference': The Social Organization of 'Migrant Workers' in Canada," Atlantis: A Women's Studies Journal 24, no. 2 (2001): 5-15; Nandita Sharma, Home Economics: Nationalism and the Making of 'Migrant Workers' in Canada (Toronto: University of Toronto Press, 2006). The latest statistics on "temporary foreign workers" in Canada show that there has recently been a significant increase in the number of people brought to Canada under this subordinated status since 2005. As per Citizenship and Immigration Canada's "Facts and Figures 2009," on December 1, 2009, there were 282,771 temporary foreign workers in Canada; see, online: http://www.cic.gc.ca/english/resources/statistics/ facts2009/temporary/02.asp (accessed July 29, 2010). For comparative Canadian statistics, see also Delphine Nakache and Paula J. Kinoshita, "The Canadian Temporary Foreign Worker Program: Do Short-Term Economic Needs Prevail over Human Rights Concerns?" Study no. 5 (Institute for Research on Public Policy, May 2010), online: http://www. irpp.org/pubs/IRPPstudy/IRPP_Study_no5.pdf (accessed July 29, 2010).

6. Mae Ngai, Impossible Subjects: Illegal Aliens and the Making of Modern America (Princeton: Princeton University Press, 2004); see also Peter Nyers, "No One Is Illegal between City and Nation," in Acts of Citizenship, ed. Engin Isin and Greg M. Nielson (London: Zed, 2008).

7. Étienne Balibar, We, the People of Europe? Reflections on Transnational Citizenship (Princeton and Oxford: Princeton University Press, 2004), 109.

8. Michael Walzer, "The Distribution of Membership," in Boundaries: National Autonomy and Its Limits, ed. Peter G. Brown and Henry Shue (Lanham, MD: Rowman and Littlefield, 1981).

9. Peter Nyers, "The Accidental Citizen: Acts of Sovereignty and (Un)Making Citizenship," Economy and Society 35, no. 1 (2006): 22-41.

10. Bridget Anderson, "Migration, Immigration Controls and the Fashioning of Precarious Workers," Work, Employment and Society 24, no. 2 (2010): 300-317.
11. Eithne Luibheid, Entry Denied: Controlling Sexuality at the Border (Minneapolis: University of Minnesota Press, 2002); Sarah Van Walsum, The Family and the Nation: Dutch Family Migration Policies in the Context of Changing Family Norms (Newcastle: Cambridge Scholars Publishing, 2008).

12. Citizenship and Immigration Canada, "Study GuideDiscover Canada: The Rights and Responsibilities of Citizenship" (2009) online: http://www.cic.gc.ca/english/ resources/publications/discover/index.asp (accessed July 13, 2010).

13. M. Jacqui Alexander and Chandra Talpade Mohanty, Feminist Genealogies, Colonial Legacies, Democratic Futures (New York: Routledge, 1997); Chandra Talpade Mohanty, Feminism Without Borders: Decolonizing Theory, Practicing Solidarity (Durham: Duke University Press, 2003); Carole Boyce Davies, Black Women, Writing and Identity: Migrations of the Subject (London: Routledge, 1994).

14. Antoinette Burton, "Introduction: On the Inadequacy and the Indispensability of the Nation," in After the Imperial Turn: Thinking with and through the Nation, ed. Antoinette Burton (Durham: Duke University Press, 2003).

15. See, for example, Alison Brysk and Gershon Shafir, eds., People Out of Place: Globalization, Human Rights, and the Citizenship Gap (New York: Routledge, 2004); Brian Barry and Robert E. Goodin, eds., Free Movement: Ethical Issues in the Transnational Migration of People and Money (London and New York: Harvester Wheatsheaf, 1992); T. Basok, S. Ilcan, and J. Noonan, "Citizenship, Human Rights and Social Justice," Citizenship Studies 10, no. 3 (2006): 267-273; Philip Cole, Philosophies of Exclusion: Liberal Political Theory and Immigration (Edinburgh: Edinburgh University Press, 2000).

16. Linda Bosniak, "Human Rights, State Sovereignty and the Protection of Undocumented Migrants," in Irregular Migration and Human Rights: Theoretical, European and International Perspectives, ed. B. Bogusz, R. Cholewinski, A. Cygan, and E. Szyszczak (Leiden: Martinus Nijhoff, 2004); Alice Bloch, "The Right to Rights? Undocumented Migrants from Zimbabwe Living in South Africa,." Sociology 44, no. 2 (2010): 233-250.

17. Donna Baines and Nandita Sharma, "Is Citizenship a Useful Concept in Social Policy Work? Non-Citizens: The Case of Migrant Workers in Canada," Studies in Political Economy 69 (Autumn 2003): 75-107; Linda Bosniak, "Critical Reflections on "Citizenship" as a Progressive Aspiration" in Labour Law in an Era of Globalization: Transformative Practices \& Possibilities, ed. Joanne Conaghan, Richard Michael Fischl,and Karl Klare (Oxford: Oxford University Press, 2002): 339, 340; Francis B. Nyamnjoh, Insiders and Outsiders: Citizenship and Xenophobia in Contemporary Southern Africa (London: Zed, 2006).

18. For an argument for "transnational labour citizenship" see Jennifer Gordon, "Transnational Labor Citizenship," Southern California Law Review 80, no. 3 (2007): 503-588. 
19. Michael Neocosmos, From 'Foreign Natives' to 'Native Foreigners' Explaining Xenophobia in Post-apartheid South Africa, Citizenship and Nationalism, Identity and Politics. (Dakar: CODESRIA, 2010).

20. Nandita Sharma, "Travel Agency: A Critique of AntiTrafficking Campaigns," Refuge 21, no. 3 (2003): 53-65; Kamala Kempadoo, "Victims and Agents of Crime: The New Crusade against Trafficking," in Global Lockdown: Race, Gender, and the Prison-Industrial Complex, ed. Julia Sudbury (New York and London: Routledge, 2005): 35-55; Kamala Kempadoo, "The War on Human Trafficking in the Caribbean," Race and Class 49, no. 2 (2007): 79-85; Bridget Anderson, "Where's the Harm in That? Immigration Enforcement, Trafficking and Migrants' Rights' (paper presented at workshop Human Rights, Victimhood and Consent, University of Bergen, 10-12 June 2010); Laura Brace, "The Opposites of Slavery: Contract, Freedom and Labour" (paper presented at workshop Human Rights, Victimhood and Consent, University of Bergen, 10-12 June 2010).

21. United Kingdom Home Office, "Enforcing the Rules: A Strategy to Ensure and Enforce Compliance with Our Immigration Laws" (London: Home Office, 2007).

22. Kempadoo, "The War on Human Trafficking in the Caribbean," 81.

23. Brace.

24. Nicholas de Genova, "The Deportation Regime: Sovereignty, Space, and the Freedom of Movement," in Deported: Removal and the Regulation of Human Mobility, ed. Nicholas de Genova and Nathalie Peutz (Durham: Duke University Press, 2010); Sandro Mezzadra and Brett Neilson, "Border as Method, or, the Multiplication of Labor," European Institute for Progressive Cultural Policies, online: http:// eipcp.net/transversal/0608/mezzadraneilson/en (accessed, July 21, 2010).

25. David Bacon, Illegal People: How Globalization Creates Migration and Criminalizes Immigrants (Boston: Beacon Press, 2008); Hector L. Delgado, New Immigrants, Old Unions: Organizing Undocumented Workers in Los Angeles (Philadelphia: Temple University Press, 1993); Kim Moody, "Harvest of Empire: Immigrant Workers' Struggles in the USA," in Socialist Register 2008 (Global Flashpoints: Reactions to Imperialism and Neoliberalism), ed. Leo Panitch and Colin Leys (London: 2007); Ruth Milkman, ed., Organizing Immigrants: The Challenge for Unions in Contemporary California (Ithaca: Cornell University Press, 2000); Ruth Milkman, L.A. Story: Immigrant Workers and the Future of the U.S. Labor Movement (New York: Russell Sage, 2006); Jennifer Gordon, Suburban Sweatshops: The Fight for Immigrant Rights (Cambridge, MA: Belknap Press of Harvard University Press, 2005); Immanuel Ness, Immigrants, Unions, and the U.S. Labor Market (Philadelphia: Temple University Press, 2005); Ai-Jen Poo and Eric Tang, "Domestic Workers Organize in the Global City," in The Fire This Time: Young Activists and the New
Feminism, ed. Vivien Labaton and Dawn Lundy Martin (New York: Anchor, 2004).

26. Gordon, "Transnational Labor Citizenship." Also, for an interesting exchange within the US labour context on the politics of open borders, see Dan LaBotz and Ana Avendano, "Open Borders? A Debate," New Labor Forum 17, no. 1 (Spring 2008): 9-24.

27. Ibid.

28. Donna Gabaccia, "The 'Yellow Peril' and the 'Chinese of Europe': Global Perspectives on Race and Labor, 18151930," in Migration, Migration History, History: Old Paradigms and New Perspectives, ed. Jan Lucassen and Leo Lucassen (Bern: Peter Lang, 1997), 186 (emphasis in the original).

29. Ibid.,195.

30. Cynthia Wright, "Against Illegality: New Directions in Organizing By and With Non-Status People in Canada," in Sociology for Changing the World: Social Movements/Social Research, ed. Caelie Frampton, et al. (Halifax: Fernwood, 2006); Peter Nyers, "Abject Cosmopolitanism: The Politics of Protection in the Anti-Deportation Movement," Third World Quarterly 24, no. 6 (2003): 1069-1093.

31. Silvia Federici, Caliban and the Witch: Women, the Body and Primitive Accumulation (Brooklyn, NY: Autonomedia, 2004).

32. Lisa Lowe, "The Intimacies of Four Continents", in Haunted by Empire: Geographies of Intimacy in North American History, ed. Ann Laura Stoler (Durham: Duke University Press, 2006).

33. For a recent contribution, see Seyla Benhabib and Judith Resnik, eds., Migrations and Mobilities: Citizenship, Borders, and Gender (New York: New York University Press, 2009).

34. Bob Sutcliffe, "Migration and Citizenship: Why Can Birds, Whales, Butterflies and Ants Cross International Frontiers More Easily than Cows, Dogs and Human Beings?" in Migration and Mobility: The European Context, ed. Subrata Ghatak and Anne Showstack Sassoon (New York: Palgrave, 2001).

35. For some suggestive remarks on challenging "nationalist historiographies" in Asian context, see Sucheta Mazumdar, "Localities of the Global: Asian Migrations between Slavery and Citizenship," International Review of Social History 52 (2007): 124-133.

36. Jan Lucassen and Leo Lucassen, "Migration, Migration History, History: Old Paradigms and New Perspectives," in Migration, Migration History, History: Old Paradigms and New Perspectives, ed. Jan Lucassen and Leo Lucassen (Bern: Peter Lang, 1997). See also Leo Lucassen, "Migration and World History: Reaching a New Frontier," International Review of Social History 52 (2007): 89-96.

37. For some reflections on understanding "internal" and "international" migrations together, see David Feldman, "Global Movements, Internal Migration, and the Importance of Institutions," International Review of Social History 52 (2007): 105-109. 
38. On vagabonds in European context, see Leo Lucassen, "Eternal Vagrants? State Formation, Migration, and Travelling Groups in Western-Europe, 1350-1914," in Migration, Migration History, History: Old Paradigms and New Perspectives, ed. Jan Lucassen and Leo Lucassen (Bern: Peter Lang, 1997).

39. John Torpey, The Invention of the Passport: Surveillance, Citizenship, and the State (Cambridge and New York: Cambridge University Press, 2002). See also Radhika Viyas Mongia, "Race, Nationality, Mobility: A History of the Passport," in After the Imperial Turn: Thinking with and through the Nation, ed. Antoinette Burton (Durham: Duke University Press, 2003).

40. Torpey.

41. Dimitri Papadopoulos, Niamh Stephenson, and Vasily Tsianos, Escape Routes: Control and Subversion in the Twenty-First Century (London and Ann Arbor, MI: Pluro Press, 2008), 55.

42. Mazumdar, 128.

43. Aderanti Adepoju, "Creating a Borderless West Africa: Constraints and Prospects for Intra-Regional Migration," in Migration without Borders: Essays on the Free Movement of People, ed. Antoine Pecoud and Paul de Guchteneire (New York: Berghahn Books and UNESCO, 2007), 163.

44. Papadopoulos, Stephenson, and Tsianos, 48.

45. Benedict Anderson, Imagined Communities: Reflections on the Origin and Spread of Nationalism (London: Verso, 1991), 3.

46. William Walters, "Acts of Demonstration: Mapping the Territory of (Non-)Citizenship," in Acts of Citizenship, ed. Engin Isin and Greg M. Nielson (London: Zed, 2008); see also N. Rodriguez, "The Battle for the Border: Notes on Autonomous Migration, Transnational Communities, and the State," Social Justice 23, no. 3 (1996): 21-37.

47. Étienne Balibar, "What We Owe to the Sans-Papiers," in Social Insecurity, ed. L. Guenther and C. Heesters (Toronto: Anansi, 2000), 42.

48. Sandro Mezzadra and Brett Neilson, "Border as Method, or, the Multiplication of Labor," European Institute for Progressive Cultural Policies, online: http://eipcp.net/ transversal/0608/mezzadraneilson/en (accessed July 21, 2010).

49. Editorial, Wall Street Journal, July 3, 1984; Jason Riley, The Case for Open Borders: Six Common Arguments against Immigration and Why They Are Wrong (New York: Gotham Books, 2008).

50. David Harvey, The New Imperialism (Oxford: Oxford University Press, 2003).

51. Kristin Ross, May 68 and Its Afterlives (Chicago: University of Chicago Press, 2002).

52. Cole.

53. Ibid.

54. Michael Walzer, Spheres of Justice: A Defense of Pluralism and Equality (Basic Books, 1983); Walzer, "The Distribution of Membership"; Gary Freeman, "Migration and the Political
Economy of the Welfare State," in Annals of the American Academy of Political and Social Science 485, no. 1 (1986): 51-63.

55. Theresa Hayter, Open Borders: The Case against Immigration Controls (London: Pluto Press, 2004).

56. Peter Linebaugh, The Magna Carta Manifesto: Liberties and Commons for All (Berkeley: University of California Press, 2007), 45.

57. Ibid.

58. Ibid.

59. Ibid

60. Ibid.

61. Ibid.

62. Thomas Dye, “The Maka'ainana Transformation in Hawaii: Archaeological Expectations Based on the Social Effects of Parliamentary Enclosure in England," (Honolulu: T. S. Dye and Colleagues, Archaeologists, Inc., 2009).

63. Walter Mignolo, "The Many Faces of Cosmo-polis: Border Thinking and Critical Cosmopolitanism," Public Culture 12, no. 3 (2000): 721-748.

64. "Statement on the Xenophobic Attacks in Johannesburg" (May 2008), online: http://www.abahlali.org/node/3582 (accessed July 25, 2010).

65. Michael Billig, Banal Nationalism (London: Sage, 1995).

66. Ibid.

67. For discussion, see Jacqueline Bhabha, "Get Back to Where You Once Belonged': Identity, Citizenship, and Exclusion in Europe," Human Rights Quarterly 20, no. 3 (1998): 592-627.

Bridget Anderson is a senior research fellow at the Centre on Migration, Politics and Society at the University of Oxford. Her research interests include migration, low-waged labour markets, "victimhood," and immigration enforcement. Theoretically this empirical work leads to questions of the relation of the state to the construction of certain categories of person as being worthy of protection or of work and others as threatening or dishonourable, and also to considerations of migrant subjectivity and theories and practices of citizenship, She has worked as an adviser and activist, with a range of migrants' organizations and trade unions.

Nandita Sharma is an associate professor in the Department of Ethnic Studies and the Department of Sociology at the University of Hawaii at Manoa. Her research interests address themes of human migration, migrant labour, national state power, ideologies of racism and nationalism, processes of identification and self-understanding, and social movements for justice. Sharma is an activist scholar whose research is shaped by the social movements she is a part of. In 1999 she helped to form Open the Borders!, an organization committed to the development and advancement of a No Borders politics. 
Cynthia Wright teaches in the School of Women's Studies and the Department of Geography at York University, Toronto. Her diverse research and teaching interests include: the state production of "illegality" and the origins of immigration controls; social justice movements, especially migrant activism; transnational feminism and sexuality studies; twentiethcentury "international history from below," including migration practices; colonialism and imperialism; and methodologies for transnational history. She has been part of several research projects on im/migration involving alliances among scholars, scholar/activists, community services, and migrant justice campaigns.

(C) Bridget Anderson, Nandita Sharma and Cynthia Wright, 2009. This open-access work is licensed under a Creative Commons AttributionNonCommercial 4.0 International License, which permits use, reproduction and distribution in any medium for non-commercial purposes, provided the original author(s) are credited and the original publication in Refuge: Canada's Journal on Refugees is cited. 